\title{
Tooth mobility and periodontal therapy
}

\author{
Thomas J. Fleszar, James W. Knowles, Edith C. Morrison, Frederick G. Burgett, \\ Robert R. Nissle and Sigurd P. Ramfjord
}

The University of Michigan School of Dentistry, Department of Periodontics, Ann Arbor, Michigan, U. S. A.

\begin{abstract}
Abstracr. Data collected as part of an 8-year longitudinal study on periodontal therapy involving 82 patients and 1974 teeth were analyzed to determine if tooth mobility influenced the results of treatment.

For each patient, pocket depth, attachment level and tooth mobility were scored clinically at the initial appointment, and once a year for 8 years following periodontal therapy. The treatment consisted of scaling, oral hygiene instruction, occlusal adjustment, periodontal surgery (curettage, modified Widman or pocket elimination), followed by recall prophylaxes every 3 months. Tooth mobility data on a scale of $0-3$ were related to changes in attachment levels for three grades of severity of periodontal disease, based on initial pocket depth $(1-3 \mathrm{~mm}, 4-6 \mathrm{~mm}$, and $7+\mathrm{mm})$. Mean patient attachment changes were calculated from teeth in the same severity category for each patient. The data were analyzed by one-way analysis of variance and Scheffe's multiple comparison procedure to test the hypothesis of equal effects of tooth mobility on the results of the treatment for the three severity groups over 8 years.

The results indicate that there is a statistically significant relationship between original tooth mobility and the change in level of attachment following treatment. Pockets of clinically mobile teeth do not respond as well to periodontal treatment as do those of firm teeth exhibiting the same initial disease severity.
\end{abstract}

The significance of tooth mobility in the etiology and treatment of periodontal disease is controversial. Only a few studies have evaluated the influence of tooth mobility on the results of periodontal therapy (Glickman et al. 1966, Noyes \& Clark 1968, Rosling et al. 1976b, Lindhe \& Ericsson 1976). As a consequence, clinical decisions relative to occlusal therapy as part of periodontics have tended to be subjective.

This study was undertaken to determine whether any relationship exists between tooth mobility and clinically measurable responses to conventional periodiontal treatment.

\section{Materlal and Methods}

The data used for this analysis had been collected over 8 years as part of a Michigan Longitudinal Study (Ramfjord et al. 1973,1975 ). Included are the results from 82 patients who had completed at least the first 1-year recall and scoring. They had a total of 1974 teeth. At 5 years, 72 patfents remained, and after 8 years, 43 patients with 1083 teeth still were available. 
The criteria for patient selection and the experimental design of this Michigan Study have been published in previous papers (Ramfjord et al. 1973, 1975). For clarity, however, a summary is included.

Pocket depth and attachment level were recorded according to the criteria suggested by Ramfjord $(1959,1967)$. Tooth mobility was scored as follows:

M0: Physiologic mobility; firm
tooth

M1: Slightly increased mobility

M2: Definite to considerable increase in mobility, but no impairment of function

M3: Extreme mobility; a "loose" tooth that would be uncomfortable in function.

Following initial scoring, scaling, root planing, oral hygiene instruction, and an occlusal adjustment, all patients on a randomized basis had each half of their mouth treated with one of the following surgical procedures: (1) subgingival curettage, (2) modified Widman flap surgery, or (3) pocket elimination surgery. The patients were recalled every 3 months for prophylaxis by a dental hygienist and were scored annually by the same periodontist.

To facilitate data interpretation, initial disease severity was determined by creating three severity categories based on initial pocket/sulcus depths: $1-3 \mathrm{~mm}, 4-6 \mathrm{~mm}$, and $7-12 \mathrm{~mm}$.

Data analysis related to initial tooth mobility, initial disease severity and response to therapy (change in level of attachment) was then performed. To determine if significant relationships existed between these factors, programs of the Michigan Interactive Data Analysis System (MIDAS) were used.

Patient means were generated satisfying the assumption of independence of the ex- perimental unit thus allowing statistical testing of differences. Within each patient, the means were calculated by first collapsing into groups all sites of the same initial severity located on teeth of equal initial mobility. Then, a yearly mean change of attachment was calculated for each of these groups. Patient means, therefore, were calculated for each level of mobility within a specific severity category.

A one-way analysis of variance (ANOVA) was used to test the hypothesis of equal changes in level of attachment after treatment in the four levels of tooth mobility for each severity category (Tables 1,2 and 3 ). If the hypothesis of equal levels of attachment was rejected at the 0.05 level of significance using ANOVA, Scheffe's method for multiple comparisons was used to determine which of the contrasts between categories of tooth mobility differed (Tables 4, 5 and 6). For the purpose of this study, data from all three modalities of periodontal treatment were pooled.

\section{Reaults}

By the first year following treatment, a separation of the mobility related attachment curves is evident at all levels of severity (Figs. 1, 2 and 3). By the second year, the differences between the curves become more distinct in the $1-3$ and $4-6$ $\mathrm{mm}$ severity groups. The curves of the $7-12 \mathrm{~mm}$ group fluctuate little during this same time period, however.

As evidenced in Tables 4, 5 and 6, most of the differences between the curves are statistically significant $(P<0.05)$. One exception relates to the " 0 " and " 1 " mobility groups of the 1-3 and 4-6 mm severity levels. In spite of graphically distinct change in attachment curves, sites associated with these groups are not significantly different from one another. 

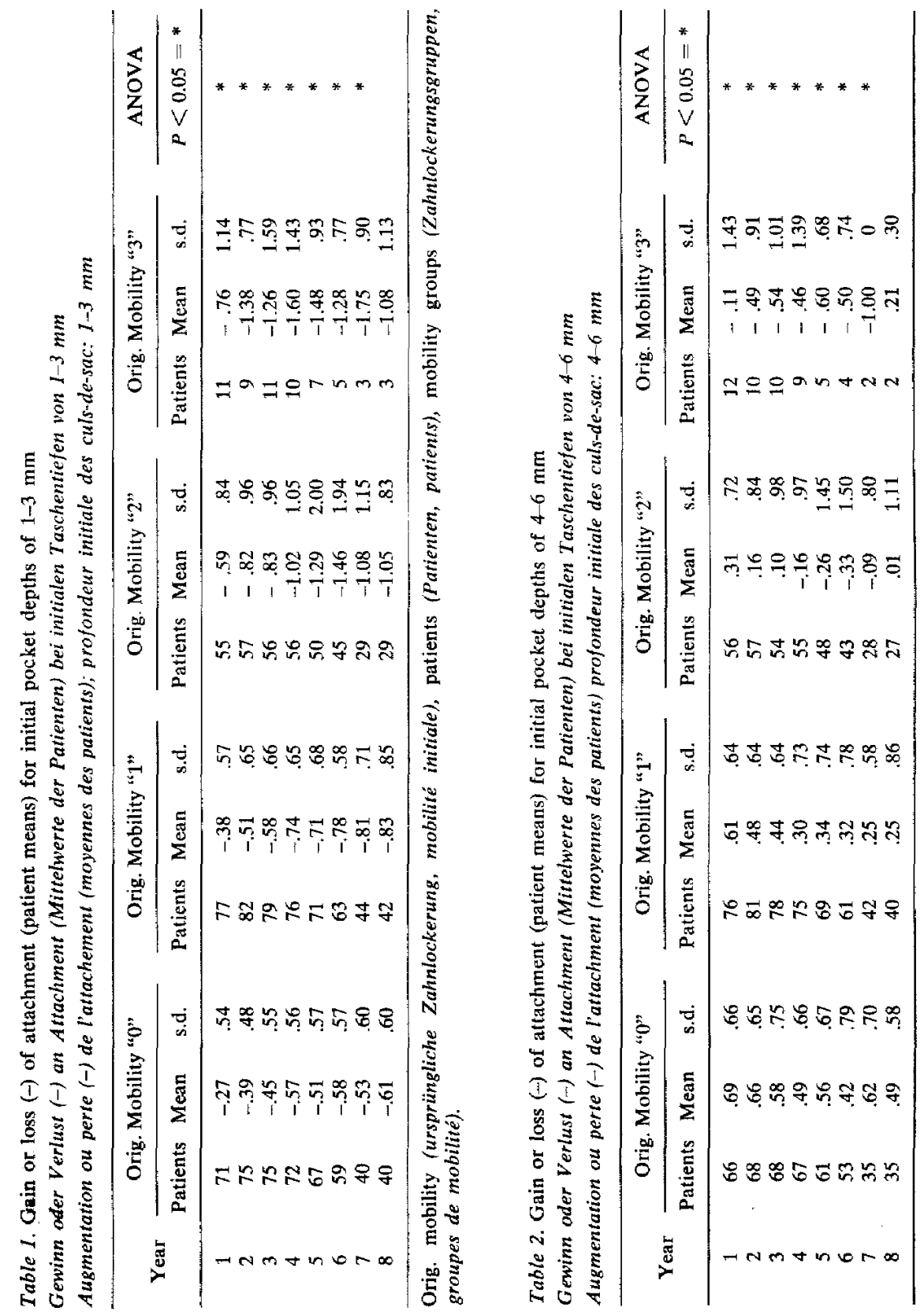


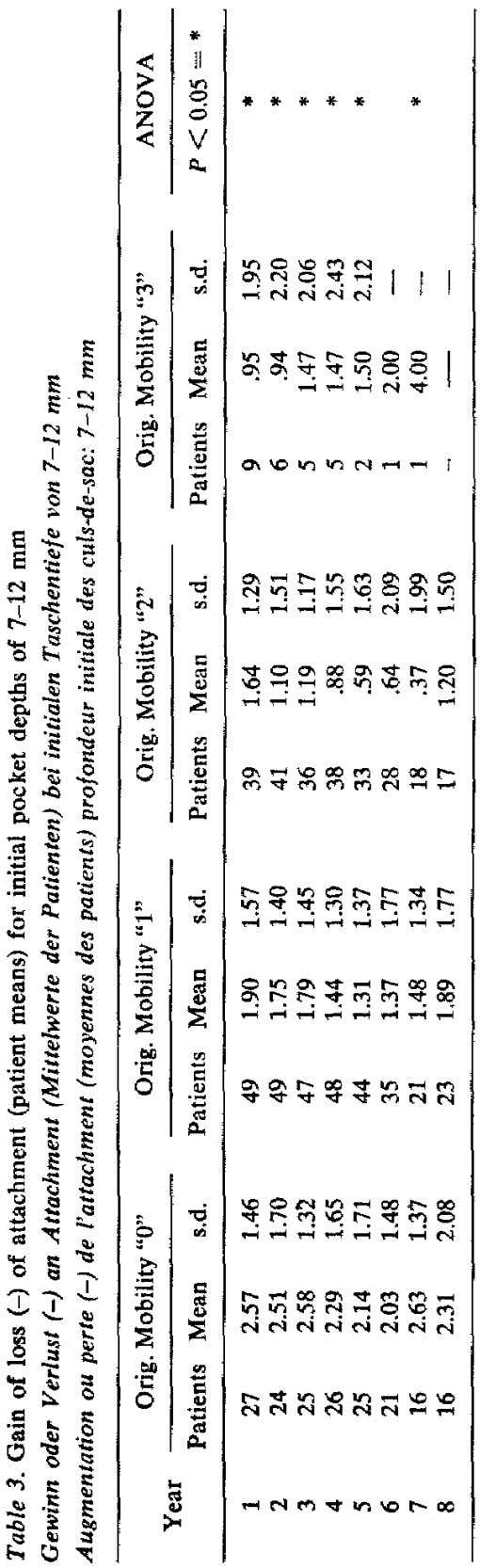

A lack of statistical significance $(P<$ 0.05 ) also can be noted in many of the contrasts associated with the later years of the study and with the most severe level of tooth mobility (" 3 "). This is understandable since fewer values comprise the computed means as time, mobility and severity increase. This circumstance leads to greater discrepancies in the variances and subsequently to decreased levels of significance.

As with previously reported data (Ramfjord et al. 1975, Knowles et al. 1979), "non-diseased" sites (1-3 mm) experience a loss of attachment (Fig. 1). In this analysis the amount of the loss can be related to the initial tooth mobility with both the " 2 " and " 3 " mobility groups reflecting a loss of approximately $1 \mathrm{~mm}$ by the second year.

Close examination of the "moderately diseased" sites (4-6 mm) (Fig. 2) reveals that only those sites associated with " 0 " and " 1 " mobility evidence any gain in attachment. The sites associated with a " 2 " mobility gain initially, but then return to baseline, while those in the " 3 " category actually lose attachment within the first 2 years post-therapy.

The most dramatic separation of the change in attachment curves can be observed in the "severe" disease category (7-12 mm) (Fig. 3). There is approximately a $0.5 \mathrm{~mm}$ difference between each of the curves.

In all severity levels refative stability of the change in attachment curves can be observed after the second year.

\section{Discusaion}

Reviewing the data from all severity levels, two observations can be made: the relationship between tooth mobility and the post-therapeutic level of attachment is es- 
Table 4. Difference of the means for initial pocket depths of $1-3 \mathrm{~mm}$ Unterschied zwischen den Mittelwerten bei initialen Taschentiefen von 1-3 mm Différence entre les moyennes; profondeur initiale des culs-de-sac: 1-3 $\mathrm{mm}$

\begin{tabular}{|c|c|c|c|c|c|c|c|c|}
\hline & Year & & & & & & & \\
\hline Mobility groups & 1 & 2 & 3 & 4 & 5 & 6 & 7 & 8 \\
\hline $0 \& 1$ & .17 & .12 & .13 & .18 & .20 & .20 & .28 & .21 \\
\hline $0 \& 2$ & $.32^{4 *}$ & $.43^{* *}$ & $.38^{* *}$ & $.45^{* *}$ & $.78^{* *}$ & $.88 * *$ & $.55^{* *}$ & $.43^{* \%}$ \\
\hline $0 \& 3$ & $.49^{*}$ & $1.00^{* * *}$ & $.81 * *$ & $1.03 * *$ & $.96^{* *}$ & .70 & $1.22 * *$ & .47 \\
\hline $1 \& 2$ & .21 & $31^{* * *}$ & .25 & $.28^{* *}$ & $.58 * *$ & $.68^{* *}$ & .27 & .22 \\
\hline $1 \& 3$ & .37 & $.88 * *$ & $.68 * *$ & $.86^{* *}$ & .77 & .50 & .94 & .26 \\
\hline $2 \& 3$ & .17 & $.57 * *$ & .43 & $.58 * *$ & .18 & -.18 & .67 & .04 \\
\hline
\end{tabular}

Scheffe's $P<0.05=* *$

Table 5. Difference of the means for initial pocket depths of $4-6 \mathrm{~mm}$ Unterschied zwischen den Mittelwerten bei initialen Taschentiefen von 4-6 mm Différence entre les moyennes; profondeur initiale des culs-de-sac. 4-6 mm

\begin{tabular}{|c|c|c|c|c|c|c|c|c|}
\hline & Year & & & & & & & \\
\hline Mobility groups & 1 & 2 & 3 & 4 & 5 & 6 & 7 & 8 \\
\hline $0 \& 1$ & .07 & .19 & .14 & .19 & .22 & .09 & .37 & .24 \\
\hline $0 \& 2$ & $.38 \%$ & $.51 * *$ & $.49 * *$ & $.65^{* *}$ & $.82^{* *}$ & $.74^{* *}$ & .71 & $.48^{* *}$ \\
\hline $0 \& 3$ & $.79^{4 *}$ & $1.15^{* * *}$ & $1.13^{* *}$ & $.96^{* *}$ & $1.16^{* *}$ & .91 & 1.62 & .27 \\
\hline $1 \& 2$ & $.31 *$ & $32^{* *}$ & $.35^{* *}$ & $.46^{* *}$ & $.59 * *$ & $.65^{* *}$ & .34 & .24 \\
\hline $1 \& 3$ & $.72^{* 4}$ & $.97 * *$ & $.99 * *$ & $.76^{* *}$ & $.93^{* *}$ & .82 & 1.25 & .03 \\
\hline $2 \& 3$ & .41 & $.65^{* *}$ & $.64^{* *}$ & .31 & .34 & .17 & .91 & -.20 \\
\hline
\end{tabular}

Scheffe's $P<0.05=* *$

Table 6. Difference of the means for initial pocket depths of 7-12 mm

Unterschied zwischen den Mittelwerten bei initialen Taschentiefen von 7-12 mm

Différence entre les moyennes; profondeur initiale des culs-de-sac; 7-12 mm

\begin{tabular}{lccccccccc}
\hline Mobility groups & Year & 1 & 2 & 3 & 4 & 5 & 6 & 7 & 8 \\
\hline $0 \& 1$ & $\&$ & .67 & $.76^{* *}$ & $.79^{* *}$ & $.85^{* *}$ & $.83^{* *}$ & .66 & $1.15^{* *}$ & .42 \\
$0 \& 2$ & $.94^{* *}$ & $1.42^{* *}$ & $1.39^{* *}$ & $1.41^{* *}$ & $1.55^{* *}$ & $1.39^{* *}$ & $2.25^{* *}$ & 1.11 \\
$0 \& 3$ & $1.62^{* *}$ & $1.57^{* *}$ & 1.11 & .83 & .64 & .03 & -1.38 & - \\
$1 \& 2$ & .27 & $.66^{* *}$ & $.60^{* *}$ & .55 & $.72^{* *}$ & .73 & $1.11^{* *}$ & .69 \\
$1 \& 3$ & .95 & .81 & .32 & -.03 & -.19 & -.63 & -2.52 & - \\
$2 \& 3$ & .68 & .15 & -.28 & -.58 & -.91 & -1.36 & $-3.63^{* *}$ & - \\
\hline
\end{tabular}

Scheffe's $P<0.05=* *$

tablished by the first year with some minor adjustment occurring by the second, and after the second year only small changes in the attachment curves are observed.
In the previous reports, (Ramfjord et al. 1968, 1973, 1975, Ramfjord 1977, Knowles et al. 1979) teeth of different mobilities were always considered equal when treat- 


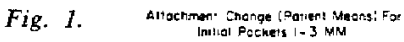

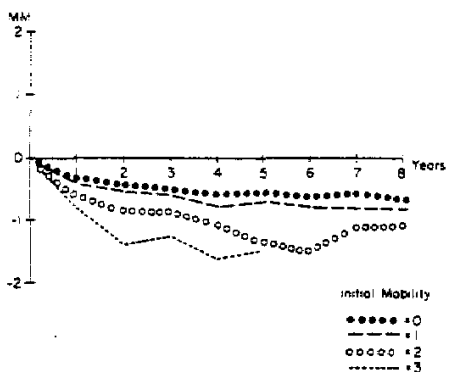

Attachmentveränderung (Mittelwerte der Patienten) bei initialen Taschentiefen von $1-3 \mathrm{~mm}$. Modification de lattachement (moyennes des patients); culs-de-sac initiaux: $1-3 \mathrm{~mm}$. Mobilité initiale $0,1,2$ ou 3.

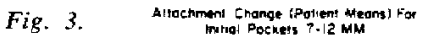

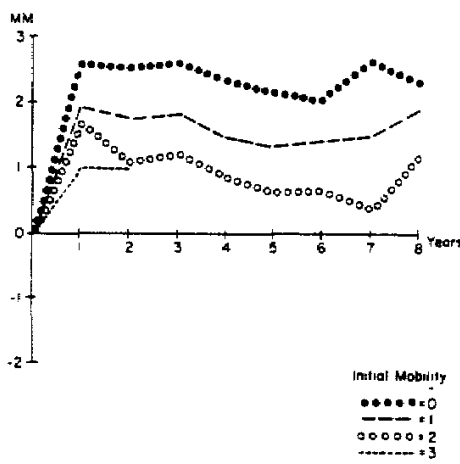

Attachmentveränderung (Mittelwerte der Patienten) bei initialen Taschentiefen von 7-12 $\mathrm{mm}$.

Modification de l'attachement (moyennes des patients); culs-de-sac initiaux: $7-12 \mathrm{~mm}$. Mobilité initiale $0,1,2$ ou 3.

ment results were evaluated. By reevaluating the data for each level of tooth mobility, a masking effect from pooling the teeth was eliminated. As an example, consider the moderate disease sites pockets 4-6 mm) (Fig. 2). Earlier studies (Ramfjord et al, 1975, Ramfjord 1977, Knọwles

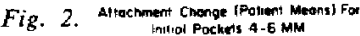

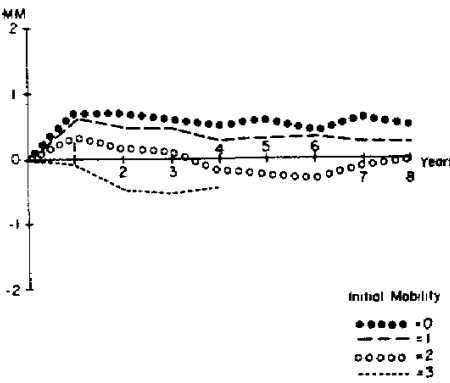

Attachmentveränderung (Mitteiwerte der Patienten) bei initialen Taschentiefen von 4-6 mm. Modification de lattachement (moyennes des patients); culs-de-sac initiaux: $4-6 \mathrm{~mm}$. Mobilité initiale $0,1,2$ ou 3.

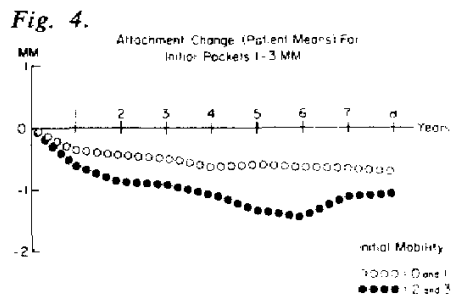

Attachmentveränderung (Mittelwerte der Patienten) bei initialen Taschentiefen von $1-3 \mathrm{~mm}$. Modification de lattachement (moyennes des patients); culs-de-sac initiaux: $1-3 \mathrm{~mm}$. Mobilité initiale 0 et 1 ou 2 et 3 .

et al. 1979) reported that some gain in attachment occurred in these pockets following treatment. The present analysis shows, however, that the gain is related to initial tooth mobility. Sites associated with teeth of a " 2 " mobility do not appear to gain attachment. In fact, a slight loss can be 
Fig. 5.

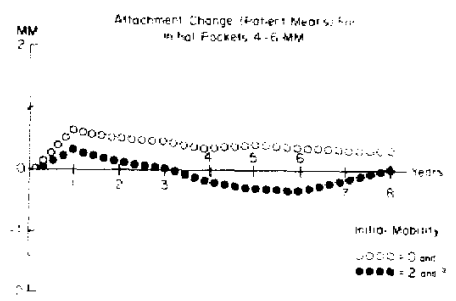

Attachmentveränderung (Mittelwerte der Patienten) bei initialen Taschentiefen von $4-6 \mathrm{~mm}$. Modification de lattachement (moyennes des patients); culs-de-sac initiaux: 4-6 mm. Mobilité initiale 0 et 1 on 2 et 3 .

observed in pockets of highly mobile (" 3 ") teeth (Fig. 2).

While the mechanisms responsible for the separation of the mobility related attachment curves are unknown, some interpretation of the data is possible. It is known that the consistent loss of attachment observed following treatment in 1-3 mm pockets can be partially explained by a statistical phenomenon known as regression towards the mean (Knowles et al. 1979). The regression phenomenon cannot explain, however, the stratification of the curves.

It could be that another process known as "leveling" may be involved. Based upon clinical and radiographic observations, variations in soft tissue and bone support tend to seek a compromise level following treatment. The deep defects will often show gain, while adjacent high levels of support may decrease (Rosling et al. 1976a). The marked loss of attachment observed in shallow pockets of highly mobile teeth ("2" and " 3 ") may be the result of such a process. It is impossible from the present data to determine whether other pockets on the highly mobile teeth were deeper than 1-3 $\mathrm{mm}$, and how much leveling took place.

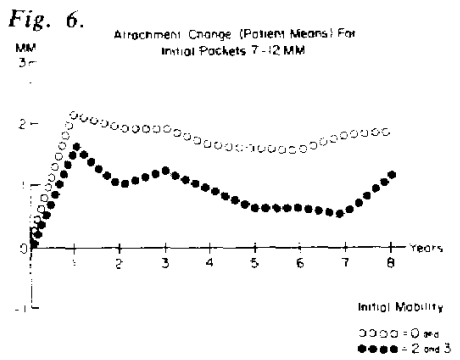

Attachmentveränderung (Mittelwerte der Patienten) bei initialen Taschentiefen von 7-12 $\mathrm{mm}$. Modification de lattachement (moyennes des patients); culs-de-sac initiaux: 7-12 mm. Mobilité initiale 0 et 1 ou 2 et 3 .

Like the regression phenomenon, leveling cannot be the entire explanation since the change in attachment curves is stratified throughout all severity levels. There must be, therefore, some process related to tooth mobility which affects all teeth during the first and possibly the second year following treatment. The implication seems to be that tooth mobility detrimentally affects healing.

Only two studies could be located which have evaluated the effect of initial tooth mobility on post-therapeutic levels of attachment and neither study indicated any significant relationship between mobility and therapeutic results (Rosling et al. 1976b, Lindhe \& Ericsson 1976). Lindhe \& Ericsson (1976) induced experimental periodontitis and trauma from occlusion (Svanberg \& Lindhe 1973) on both test and control teeth in beagle dogs. On the 280th day, both the test and control teeth were treated periodontally by removal of plaque and accretions, surgical elimination of pathologically deepened pockets, and by controlled oral hygiene. Jiggling trauma was continued only on the test teeth after this point. Ninety days later healing was evaluated through biopsy procedures. The 
authors concluded that the tissue alterations caused by trauma from occlusion did not interfere with healing following periodiontal treatment, although the apical cells of the junctional epithelium in the control teeth were located more coronally to reference notches in the teeth than those in the test (active trauma) teeth. The level of the bone crest also was significantly more coronal to the reference notches in the nontraumatized than in the traumatized teeth. It thus appears that while the persistent trauma did not interfere with healing as such, it did inhibit significantly the amount of regeneration of connective tissue attachment and bone.

Rosling et al. (1976b) reported that in a test group of humans who had received modified Widman flap surgery and strict postsurgical oral hygiene, all two and three wall osseous periodontal defects healed. It was stressed "that the infrabony pockets located adjacent to hypermobile teeth exhibited the same degree of healing as those adjacent to initially firm teeth." Healing was assessed by probing to attachment levels, radiographic analysis, and reentry. However, specific data to support the statement regarding equal healing of mobile teeth were not included in the article.

The differences between the Rosling et al. (1976b) and the present study in terms of the influence of mobility on treatment results might possibly be explained by the degree of inflammation control. Many of the patients in the present study had less than ideal oral hygiene and all were subjected to 3-month recalls rather than the 2-week program of Rosing et al. (1976b). It may be that the influence of mobility on healing in the present study was related to inflammation, and that with significant inflammation there is a stratified healing response related to degrees of mobility. This stratification did not appear in the study by Rosling et al. (1976b) perhaps be- cause they had ideal control of plaque and inflammation. A study by Polson et al. (1976) would appear to support this postulate.

The separation of the attachment curves which appeared 1 year after treatment must in some way indicate the influence of mobility on healing. The subtle changes that occurred between the first and second year in 1-3 mm and 4-6 mm pockets may be more a consequence of "leveling" than continued input from a "healing effect".

As evidenced by the relatively horizontal attachment curves (after 1 year), pockets associated with mobile teeth can be successfully treated and attachment maintained, regardless of the severity and associated tooth mobility.

Some questions might arise relative to the data gathering and analysis procedures used in this study. For example, the use of site (pocket) analysis might be questioned stating that use of individual teeth might be more appropriate in a mobility study. Since some leveling of support may occur, site analysis may not completely reflect the relationship which exists between tooth mobility and periodontal attachment changes around individual teeth.

The fact that tooth mobility patterns are significantly reduced following traditional periodontal therapy (Lindhe \& Nyman 1975, Mühlemann 1967, Rateitschak 1963, Selipsky 1976) and occlusal adjustment (Mühlemann et al. 1957, Vollmer \& Rateitschak 1975) might lead to the suggestion that yearly tooth mobility values rather than initial values should have been used in the analysis. While the data were not presented in this paper, mobility levels were reduced following treatment. However, these new levels related so closely to pretreatment mobility that no differences in results were obtained when yearly tooth mobility values were used.

Objections may also be raised relative to 
the subjective nature of the tooth mobility measurements. The Miller Index, (Miller 1938) which is similar to the one employed in this study, has been designated as being useful for diagnosis and treatment planning for practitioners, but of little value in clinical research due to its inability to discriminate accurately, and its subjectivity $\left(\mathrm{O}^{\circ}\right.$ Leary 1974).

Recently, Laster et al. (1975) found the Miller Index, when modified, to be a highly accurate, clinically acceptable method of assessing horizontal tooth mobility on an averaged basis if sizable populations are involved and the examiners are calibrated. The present study meets these criteria.

In order to avoid disagreements regarding the impact of degrees of mobility, data from mobility " 0 " and " 1 " were pooled since their differences are not significant generally (Tables 4, 5 and 6). Data from mobility " 2 " and " 3 " were atso pooled since it may be assumed that any clinician would designate these as abnormal mobility. The results from this arrangement of the data are depicted in Fig. 4, 5 and 6. These graphs clearly illustrate that pockets of clinically mobile teeth do not respond as well to periodontal treatment as do those of firm teeth exhibiting the same initial disease severity.

\section{Conciusions}

1. The change in level of attachment following periodontal therapy is related significantly to initial degrees of tooth mobility at all levels of disease severity.

2. The influence of mobility on response to treatment can be noted by the first year post-treatment and generally becomes more pronounced by the second.

3. Pockets associated with clinically mobile teeth do not respond to periodontal therapy as favorably, in terms of clinical attachment gain or loss, as do those associated with firm teeth. This is irrespective of initial disease severity.

4. Only minor changes in attachment levels within each mobility category occur after the second year of observation.

5. Clinically mobile teeth can be successfully treated and maintained.

\section{Zusammenlassung}

Zahnbeweglichkeit und Parodontaltherapie

Zur Beurteilung eventueller Abhängigkeit zwischen der Zahnbeweglichkeit und dem parodontalen Behandlungsresultat bei 82 Patienten und 1974 Zähnen, wurden anlässlich einer achtjährigen Langzeitstudie Daten gesammelt und analysiert Die Taschentiefe, das Attachmentniveau und die Zahnbeweglichkeit wurden anlässlich der Ausgangsuntersuchung bei jedem einzelnen Patienten klinisch registriert. Diese Untersuchung wurde dann während der Beobachtungszeit von acht Jahren nach der Parodontaltherapie, einmal jäkrlich wiederholt. Die Behandlung bestand aus Zahnsteinentfernung, Instruktion in oraler Hygiene, einer okklusalen Belastungsausgleichbehandlung, Parodontalchirurgie (Kurettage, modifizierter Widmanoperation oder chirurgischer Taschenentfernung) und danach, in 3-monatlichen Intervallen, in der Nachsorgeprophylaxe. Die Daten über die Zahnbeweglichkeit, gemessen anhand einer Beweglichkeitsskala von $0-3$, wurden mit den Veränderungen des Attachmentniveaus (gemessen in den 3 Graden der Schwere der Parodontalkrankheit) korreliert und ais Basis dieser $\mathrm{Zu}$ sammenstellung wurden die ursprünglichen Taschentiefen $(1-3 \mathrm{~mm}, 4-6 \mathrm{~mm}$ und $7+\mathrm{mm})$ gewählt. Die mittleren Attachmentveränderungen wurden anhand von Daten von Zähnen der gleichen "Schwerekategorie" für jeden einzelnen Patienten berechnet. Die erhaltenen Daten wurden mit Hilfe der Einwegs-Varianzanalyse und Scheffe's multipler Vergleichsprozedur analysiert, um die Hypothese des gleichen Effektes der Zahnbeweglichkeit auf die Behandlungsresultate bei den drei Gruppen mit unterschiedich schwerem Krankheitsbefall, während einer Beobachtungszeit von 8 Jahren zu testen.

Die Resultate zeigen statistisch signifikante Abhängigkeit zwischen der Ursprungsmobilität und den nach der Behandlung eintretenden Veränderungen des Attachmentniveaus. Die Taschen klinisch mobiler Zähne antworten nicht so günstig auf die Parodontaltherapie 
wie das bei klinisch festen Zähnen, mit ursprünglich gleicher Schwere des Krankheitsbefalles, beobachtet wurde.

Uber die Bedeutung der Zahnbeweglichkeit für die Ätiologie und die Behandlung der Parodontopathien bestehen gegensätzliche Auffassungen. Nur einige wenige Arbeiten haben die Bedeutung der Zahnbeweglichkeit für die Resultate parodontaler Therapie studiert (Glickman et al. 1966, Noyes \& Clark 1968 , Rosling et al. 1976b, Lindhe \& Ericsson 1976). Das hat zur Folge, dass bei klinischen Entscheidungen über die Notwendigkeit okklusaler Therapie als Bestandteil parodontaler Behandlung, subjektive Tendenzen solche Entscheidungen beeinflussen können.

Diese Studie wurde durchgeführt um festzustellen, ob Beziehungen zwischen der Zahnmobilität und der klinisch messbaren Antwort auf konventionelle parodontale Therapie bestehen.

\section{Résumé}

Mobilité dentaire et traitement parodontal

Des données recueillies au cours d'une étude longitudinale de huit années, concernant le traitement parodontal et portant sur 82 patients et 1974 dents, ont été analysées afin de déterminer si la mobilité dentaire exerce une influence sur les résultats du traitement.

Pour chaque patient, la profondeur des culsde-sac, le niveau de l'attachement et la mobilité dentaire ont été mesurés par un examen clinique, lors du rendez-vous initial et une fois par an pendant les huit ans suivant le traitement parodontal. Ce traitement consistait en: détartrage, instruction en matière d'hygiène bucco-dentaire, rectification de l'occlusion, traitement parodontal chirurgical (curetage, opération de Widman modifiée ou élimination chirurgicale des culs-de-sac), suivi de séances régulières de nettoyages des dents tous les trois mois. Les données concernant la mobilité dentaire, exprimées suivant une échelle allant de 0 à 3 , ont été mises en relation avec les modifications des niveaux de l'attachement pour trois degrés de gravité de l'atteinte, en se basant sur la profondeur initiale des culs-de-sac (1-3 $\mathrm{mm}, 4-6 \mathrm{~mm}$ et $7+\mathrm{mm}$ ). La moyenne des modifications de l'attachement des patients a été calculée pour les dents appartenant chez chacun des patients à la mème catégorie de gravité. Les données ont été analysées par une analyse de variance à une direction et par la méthode de comparaison multiple de Scheffe pour tester l'hypothèse que l'influence de la mobilité dentaire sur les résultats du traitement est la mêtme dans les trois groupes de gravité pendant les huit années.

Les résultats indiquent qu'il existe un rapport statistiquement significatif entre la mobilité dentaire initiale et la modification du niveau de l'attachement après traitement. Les culs-de-sac des dents qui présentent une mobjlité clinique ne réagissent pas aussi bien au traitement que les culs-de-sac de dents non mobiles pour lesquelles le degré initial de gravité était le même.

\section{References}

Glickman, I., Smulow, J. B., Vogel, G. \& Passamonti, G. (1966) The effect of occlusal forces on healing following mucogingival surgery. Journal of Periodontology 37, 319325.

Knowles, J. W., Burgett, F. G., Nissle, R. R., Shick, R. A., Morrison, E. C. \& Ramfjord, S. P. (1979) Results of periodontal treatment related to pocket depth and attachment level. Eight years. Journal of Periodontology 50, 225-233.

Laster, L., Landenbach, K. W. \& Stoller, N. H. (1975) An evaluation of clinical tooth mobility measurements. Journal of Periodontology 46, 603-607.

Lindhe, J. \& Ericsson, I. (1976) The influence of trauma from occlusion on reduced but healthy periodontal tissues in the dog. Journal of Clinical Periodontology 3, 110-122.

Lindhe, J. \& Nyman, S. (1975) The effect of plaque control and surgical pocket elimination on the establishment and maintenance of periodontal health. A longitudinal study of periodontal therapy in cases of advanced disease. Journal of Clinical Periodontology 2, 67-79.

Miller, S. C. (1938) Textbook of Periodontia. 1st ed., Philadelphia: Blakiston.

Mühlemann, H. R. (1967) Tooth mobility: A review of clinical aspects and research findings. Journal of Periodontology 38, 686-713.

Mühlemann, H. R., Herzog, H. \& Rateitschak, K. (1957) The quantitative evaluation of the therapeutic effect of selective grinding. Journal of Periodontology 28, 11-16.

Noyes, D. \& Clark, J. (1968) Mechanical mobility of human teeth in vivo. Abs. I.A.D.R., March, p. 76.

O'Leary, T. J. (1974) Indices for measurement of tooth mobility in clinical studies. Journal 
of Periodontal Research 9 (SuppI), 94-105. Polson, A. M., Meitner, S. W. \& Zander, H. A. (1976) Trauma and progression of marginal periodontitis in squirrel monkeys. IV. Reversibility of bone loss due to trauma alone and trauma superimposed upon periodontitis. Journal of Periodontal Research 11, 290-298.

Ramfjord, S. P. (1959) Indices for prevalence and incidence of periodontal disease. Journal of Periodontology 30, 51-59.

Ramfjord, S. P. (1967) The periodontal disease index (PDI). Journal of Periodontology 38, 602-610.

Ramfjord, S. P. (1977) Present status of the modified Widman flap procedure. Journal of Periodontology 48, 558-565.

Ramfjord, S. P., Nissle, R. R., Shick, R. A. \& Cooper, H. Jr. (1968) Subgingival curettage versus surgical elimination of periodontal pockets. Joumal of Periodontology 39, 167175.

Ramfjord, S. P., Knowles, J. W., Nissle, R. R., Shick, R. A. \& Burgett, F. G. (1973) Longitudinal study of periodontal therapy. Journal of Periodontology 44, 66-77.

Ramfjord, S. P., Knowles, J. W., Nissle, R. R., Burgett, F. G. \& Shick, R. A. (1975) Results following three modalities of periodontal therapy. Journal of Periodontology 46, 522-526.

Rateitschak, K. (1963) Therapeutic effect of local treatment on periodontal disease assessed upon evaluation of different diagnos- tic criteria. I. Changes in tooth mobility. Journal of Periodontology 34, 540-544.

Rosling, B., Nyman, S., Lindhe, J. \& Jern, B. 1976a) The healing potential of the periodontal tissues following different techniques of periodontal surgery in plaque-free dentitions. A 2-year clinical study. Journal of Clinical Periodontology 3, 233-250.

Rosling, B., Nyman, S. \& Lindhe, J. (1976b) The effect of systematic plaque control on bone regeneration in infrabony pockets. Journal of Clinical Periodontology 3, 38-53.

Selipsky, H. (1976) Osseous surgery. How much need we compromise? Dental Clinics of North America 20, 79-106.

Svanberg, G. \& Lindhe, J. (1973) Experimental tooth hypermobility in the dog. A methodological study. Odontologisk Revy 24, 269282.

Vollmer, W. H. \& Rateitschak, K. (1975) Influence of occlusal adjustment by grinding on gingivitis and mobility of traumatized teeth. Journal of Clinical Periodontology 2, 113-125.

Address:

Dr. Thomas $\boldsymbol{J}$. Fleszar

The University of Michigan

School of Dentistry

Department of Periodontics

Ann Arbor, Michigan 48709

U.S. A. 
This document is a scanned copy of a printed document. No warranty is given about the accuracy of the copy. Users should refer to the original published version of the material. 